\title{
Öğretmenlerin Öğrenen Özerkliğini Destekleme ve Sergileme Düzeyleri Arasındaki İlişkinin İncelen- mesi
}

DOI: $10.26466 /$ opus.356879

\author{
Mustafa Durmușçelebi* - Merve Çetinkaya ** \\ ** Doç. Dr., Erciyes Üniversitesi, Eğitim Fakültesi, Melikgazi / Kayseri / Türkiye \\ E-Posta: mcelebi@erciyes.edu.tr ORCID: 0000-0002-0325-7528 \\ ** Yüksek Lisans Öğr., Erciyes Üniversitesi, Eğitim Bilimleri Enstitüsü / Kayseri / Türkiye \\ E-Posta: mervecetiinkaya@gmail.com ORCID: 0000-0002-3409-7547
}

Öz

Yaşam boyu öğrenme kavramının çok önemli olduğu günümüzde, kendi kendine öğrenebilen, kendi öğrenme sorumluluğunu üstlenebilen bireyler yetiştirmek önem kazanmaktadır. Bu sebeple öğretmenlerin öğrenen özerkliğini desteklemeleri gerekmektedir. Bu araştırma, öğretmenlerin öğrenen özerkliğini destekleme düzeylerini (cinsiyet, öğretmenlerin görev bölgeleri, okul kademesi vb. gibi) çeşitli değişkenlere göre incelemeyi amaçlamaktadır. Öğretmenlerin öğrenen özerkliğini destekleme düzeylerini tespit etmeye yönelik yapılan bu araştırmanın çalışma grubunu değişik okul kademelerinde görev yapan toplam 338 öğretmen oluşturmaktadır. Tarama yöntemiyle yapılan bu çalışmada öğretmenlerin öğrenen özerkliğini destekleme düzeyleri çeşitli değiişkenler açısından betimlenmeye çalışılmıştır. Araştırmanın veri toplama aracı olarak "Öğrenen Özerkliğini Destekleme Ölçeği" kullanılmıştır. Betimsel amaçla yüzde, frekans ve ortalama tekniklerinden, fark testlerinde ise ölçek durumuna göre t-testi, anova, Mann Whitney U ve Kruskal Wallis testleri kullanılmıştır. Bulgulara göre öğretmenler genel olarak, özerklik destekleyici davranışlar "çoğu zaman" gerekli bulmakta ve bu davranışların "çoğu zaman" sergilemektedirler. Öğretmenlerin özerklik desteğginin gerekliliğ $i$ ve sergilenmesine ilişkin görüşleri arasında anlaml düzeyde farkllıklar bulunmaktadır. Bu görüşler öğretmenlerin cinsiyetlerine, çalıştıkları okul türüne, deneyim yıllarına, branşlara ve görev yaptıkları coğrafi bölgeye göre farklılaşmaktadır.

Anahtar Kelimeler: Öğrenen Özerklĭ̆i, Öğrenme Ortamları, Yapılandırmacı Yaklaşım

OPUS (c) Uluslararası Toplum Araştırmaları Dergisi-International Journal of Society Researches ISSN:2528-9527 E-ISSN : 2528-9535

http://opusjournal.net 


\title{
Investigation of the Relationship Between Teachers' Supporting and Demonstration Levels of Learning Autonomy
}

\begin{abstract}
In today when the concept of lifelong learning is very important, it is necessary to educate individuals who can learn by own and can take charge of own learning responsibilities. For this reason, teachers need to support learner autonomy. This research aims to examine the level of learner autonomy support of the teachers according to various variables. The research group of the study consists of 338 teachers working in different school levels. In this study conducted by survey model, the level of learner autonomy support of the teachers has been tried to be described in terms of various variables. "Learner Autonomy Support Scale" developed by Oğuz (2012) was used as the data collection tool for this research. Percentage, frequency and arithmetic mean analysis techniques in descriptive statistics and Mann Whitney $U$ test and Kruskal Wallis tests in difference tests were used in the data analysis procedure. According to the findings, in general teachers perceive autonomy supporting behaviors necessary "most of the time" and these behaviors are being demonstrated most of the time. There is a statistically significant difference between the teachers' views regarding the necessity of autonomy support and its demonstration. These opinions differ depending on gender, school type, professional seniortiy, fields and geographical region.
\end{abstract}

Keywords: Learning Environment, Learner Autonomy, Constructivism

OPUS (c) Uluslararası Toplum Araştırmaları Dergisi-International Journal of Society Researches ISSN:2528-9527 E-ISSN : 2528-9535

http://opusjournal.net 


\section{Giriş}

Günümüzde geleneksel eğitim anlayışı yerini yapılandırmacı eğitim anlayışına bırakmaya başlamıştır. Öğrencilerin kendi bilgilerini temele aldığ1 ve onların çabaları doğrultusunda, öğrencinin öğrenme sürecinde etkin bir şekilde rol aldığı öğrenen merkezli yapılandırmacı yaklaşım önem kazanmaktadır. Yapılandırmacılık, bilginin öğretmen tarafından sinıfta sıralarında oturan öğrencilere basit bir şekilde verilecek bir şey olmadığı inancına dayalı bir görüştür. Bilakis bilgi aktif bir şekilde öğrenenler tarafından yapılandırılır ve gelişimin zihinsel sürecinde öğrenenler bilginin ve anlamın yaratıcılarıdır (Gray, 1997). Wang'e (2011) göre bu yaklaşım öğretme yerine öğrenmeyi amaçlamaktadır ve öğrencinin öğrenme sürecinde özerk olmasına, öğrencinin öğrenmeye aktif bir şekilde katılması çok önemlidir. Yapılandırmacı yaklaşımın olduğu öğrenme ortamlarında öğrenen özerkliği desteklenmekte ve böyle öğrenme ortamlarında öğrencinin öğrenme sorumluluğunu alması önemli görülmektedir (Bay, Kaya ve Gündoğdu, 2010). Yapılandırmacı görüşü benimseyenler bilginin ve gerçeğin öğrenen tarafından oluşturulduğuna ve bunun öğrenenin zihninin dışında olmadığını savunurlar (Duffy ve Jonassen, 1992). Bu yüzden yapılandırmacılara göre, öğrenenler öğrenme sürecinde aktif katılım sağlayarak öğrenmeyi sağlarlar. Yapılandırmacı yaklaşımı savunanlar işbirliğine, öğrenen özerkliğine, üretkenliğe, yansıtıcılığa ve aktif katılıma önem vermektedirler (Wang, 2011).

$\mathrm{Bu}$ öğrenme ortamlarında öğrencilerin kendi tercihlerini yapabilmesi, kendi öğrenmelerinin sorumluluklarını alabilmesi, içsel motivasyonlarını sağlayabilmesi, bağımsız bir şekilde davranışlarını kontrol edebilmesi beklenmektedir. Öğrencilerin bu özellikleri kazanabilmesi için ise onların ihtiyaçlarının giderilmesi, gerekli motivasyonlarının sağlanabilmesi ve öğrenme süreçlerine aktif katılım göstermelerinin sağlanması gerekmektedir. Bu öğretim sürecinde ise öğretmenlerin öğrencilerinin özerkliklerini desteklemesi öğrencilerin daha etkin bir şekilde öğrenmeye katılımını sağlamaktadır (Reeve, Jang, Carrell, Jeon ve Barch, 2004).

Holec (1991), özerkliği “öğrenenin öğrenme sürecinde kendi sorumluluğunu alabilmesi” şeklinde tanımlamaktadır. Wenden'e (1991) göre özerk öğrenenler; kendi öğrenme stillerinin ve öğrenme stratejilerin farkındadırlar, öğrenmelerini sağlayan bütün görevlere etkin şekilde katılır- 
lar, risk almaya isteklidirler, iyi birer tahmincidirler. İçeriğe olduğu kadar biçime de önem verirler. Öğrenenin kendi öğrenme sürecinin sorumluluğunu alabilmesi için öğretmenlerin bu süreçte öğrencilere o becerileri kazandırmaları gerekmektedir (Gardner ve Miller, 1999). Ergür'e (2010) göre de öğrencilerin öğrenme süreçlerinin sorumluluğunu alabilecek şekilde yetiştirilebilmesi öğrenci merkezli yani öğrencilerinin gereksinim, ilgi ve beklentilerinin öncelikli olduğu ve öğrenme sürecini etkileyen hedefler, içerik, materyaller, yöntemler ve değerlendirme gibi etkenlerin öğrenci görüşleri ile zenginleştirilmesi gerekmektedir. Böyle bir öğrenme ortamı ise özerk olan ve bu becerileri öğrencilerine yansitabilecek öğretmenler sayesinde oluşturulabilmektedir.

Smith (2000), öğreten özerkliğini öğretmenin öğretme sürecinde kullanabileceği bilgi, beceri ve davranışları geliştirme yeteneği olarak tanımlamaktadır. Camilleri (1997), özerk bir öğretmenin kendisini iyi tanıması, öğrenme sürecinde bireysel etkiye ve pedagojik bilgiye, huzurlu bir öğrenme ortamı oluşturabilecek beceriye sahip olması gerektiğini belirtmiştir.

Özerkliği benimseyen ve öğrenenlerin özerkliklerini destekleyen bir öğretmenin sahip olması gereken birtakım özellikler bulunmaktadır. Smith (2003), bu özellikleri şu şekilde özetlemektedir:

- Özdenetimli öğretme kapasitesine sahip olma

- Kendi öğretme sürecini kontrol etmede özgür olma

- Özerklik niteliklerine sahip olma

Özerk öğrenme süreci uzun bir süreçtir. Bu öğrenme süreci içinde öğrenci öğretmenden aldığı bilgiler sayesinde, kendi öğrenme sorumluluğunu üstlenebilmeyi, gereksinimlerini belirleyebilmeyi, kendi öğrenmesi ile ilgili kararlar verebilmeyi ve öz değerlendirme yapabilmeyi öğrenmektedir. Bu sürecin olabilmesi için ise öğrencinin özerk olması, nasıl öğreneceğini öğrenmesi ve bu öğrenmenin olabilmesi için gerekli ortamin hazırlanmasi gerekmektedir (Aydoğdu, 2009).

Özçelik 'e (2015) göre de öğrencilerin öğrenmeyi öğrenebilmeleri ve özerk olabilmeleri uygun koşullar ve öğretmen desteği ile mümkün olabilmektedir. Eker'e (2010) göre öğrenciyi motive eden ve öğrencinin öğrenmesini engelleyen de öğretmendir. Öğretmen merkezli öğretimde 
öğretmenin rolü büyükken öğrenci merkezli öğretimde öğrenciye özerklik fırsatı tanındığ 1 ve özerkliğin gelişimine destek verildiği için bu süreçte öğretmen davranışlarının önemli bir yeri vardır. Ergür (2010), öğrencinin kendi öğrenme sürecinin sorumluluğunu alacak şekilde yetiştirilebilmesi adına öğrenme sürecini etkileyen değişkenlerin öğrenci görüşleri ile şekillendirildiği bir sınıf ortamının gerekli olduğunu, özerkliğin olduğu bir sınıf ortamının ise özerk öğretmenler tarafından oluşturulabileceğini vurgulamaktadır.

Öğrenen özerkliğini destekleyen öğretmen, öğrenenlerin ilgi ve tercihlerini ve onların ihtiyaçların göz önünde bulundurarak öğrenme sürecini planlayabilir (Reeve ve Jang, 2006). Özerklik desteği; öğretmenin öğrencilerinin bakış açılarını dikkate alma ve öğrencileri öğrenme aktivitilerine aktif katılım göstermeleri için teşvik etme dereci olarak tanımlanmaktadır (Oğuz, 2013). Deci ve Ryan (1987), özerklik desteğinin olduğu sınıf ortamlarında öğrencilerin kendilerini daha yetkin olarak gördüklerini, yüksek düzeyde özsaygı sahibi olduklarını, derse olan ilgilerinin arttığını, daha yaratıcı olduklarını ve daha olumlu duygular beslediklerini belirtmişlerdir.

$\mathrm{Bu}$ araştırmada, öğretmenlerin öğrenen özerkliğini destekleme davranışlarının gerekliliğine ve sergilenmesine ilişkin görüşlerinin belirlenmesi amaçlanmıştır. Bu amaç doğrultusunda araştırmada aşağıdaki sorulara cevap aranmıştır:

1. İlk- ortaöğretim okullarında görev yapan öğretmenlerin, öğrenen özerkliğini destekleme davranışlarının gerekliliğine ve sergilenmesine ilişkin görüşleri nedir?

2. Öğretmenlerin, öğrenen özerkliğini destekleme davranışlarının gerekliliği ve sergilenmesine ilişkin görüşleri; cinsiyete, çalıştıkları kuruma, deneyim yılına, bölüme ve görev yapılan bölgeye göre değişmekte midir?

3. Öğretmenlerin, öğrenen özerkliğini destekleme davranışlarının gerekliliği ile sergilenmesine ilişkin görüşleri arasında anlamlı bir ilişki var mıdır? 


\section{Yöntem}

\section{Araştırmanın Modeli}

Öğretmenlerin öğrenen özerkliğini destekleme ve sergilemesine ilişkin görüşlerinin belirlenmesine yönelik yapılan bu çalışma tarama yöntemiyle yapılan betimsel bir çalışmadır.

\section{Katılımcilar}

Öğretmenlerin öğrenen özerkliğini destekleme ve sergilemesine ilişkin görüşlerini ortaya çıkarmak amacıyla yapılan bu çalışmanın evrenini ilkortaöğretim okullarında görev yapan öğretmenler oluşturmaktadır. Araştırmanın örneklem grubunu ise Türkiye'nin 7 bölgesinden toplam 1071 öğretmen oluşturmaktadır. Öğretmenlerin bölgelere göre dağılımına Tablo 1'de yer verilmiştir.

Tablo 1. Öğretmenlerin çalıştıkları bölgelere ve cinsiyetlerine göre dă̆ılımı

\begin{tabular}{lllllll}
\hline \multirow{2}{*}{ Görev Yapılan Bölge } & \multicolumn{2}{l}{ Cinsiyet } & \multicolumn{3}{c}{ Toplam } \\
& \multicolumn{2}{l}{ Kadın } & & \multicolumn{2}{c}{ Erkek } & \multicolumn{3}{c}{ \% } & $\%$ & $\mathrm{f}$ & $\%$ & $\mathrm{f}$ & $\%$ \\
\hline Marmara Bölgesi & 27 & 4,3 & 18 & 4,0 & 45 & 4,2 \\
Ege Bölgesi & 19 & 3,0 & 30 & 6,7 & 49 & 4,6 \\
Akdeniz Bölgesi & 21 & 3,4 & 24 & 5,4 & 45 & 4,2 \\
Güneydoğu Anadolu Bölgesi & 102 & 16,4 & 78 & 17,4 & 180 & 16,8 \\
Doğu Anadolu Bölgesi & 99 & 15,9 & 57 & 12,7 & 156 & 14,6 \\
Karadeniz Bölgesi & 16 & 2,6 & 19 & 4,2 & 35 & 3,3 \\
İç Anadolu Bölgesi & 339 & 54,4 & 222 & 49,6 & 561 & 52,4 \\
Toplam & 623 & 100,0 & 448 & 100,0 & 1071 & 100,0 \\
\hline
\end{tabular}

Araştırmaya katılan katılımcıların demografik özellikleri incelendiğinde 623 kadın ve 448 erkek katılımcının olduğu görülmektedir. Katılımcıların çoğunluğunu İç Anadolu Bölge'sinde görev yapmakta olan öğretmenler iken katılımcı sayısını sırasıyla Güneydoğu Anadolu Bölgesi, Doğu Anadolu Bölgesi, Marmara Bölgesi, Akdeniz Bölgesi, Ege Bölgesi ve Karadeniz Bölgesi izlemektedir.

Veri Toplama Araçları 
Bu araştırmada veri toplama aracı olarak Oğuz (2012) tarafından geliştirilen “Öğrenen Özerkliğini Destekleme Ölçeği”" kullanılmıştır. Ölçeğin özerklik destekleyici davranışların gerekliliği için hesaplanan Cronbach Alpha katsayısı 0,85 olarak, özerklik destekleyici davranışların sergilenmesi için hesaplanan Cronbach Alpha katsayısı ise 0,89 olarak bulunmuştur.Veri toplama aracı iki bölümden oluşmaktadır. İlk bölümde, öğretmenlerin kişisel bilgileri sorulmuştur. İkinci bölümde ise, öğretmenlerin, hem öğrenen özerkliğini destekleme davranışlarını ne düzeyde gerekli gördüklerine hem de bu davranışları ne düzeyde sergilediklerine ilişkin görüşlerini belirlemeye yönelik 32 madde yer almaktadır.

\section{Verilerin Analizi}

Araştırmada alt problemler doğrultusunda betimsel amaçla yüzde, frekans ve ortalama tekniklerinden, fark testlerinde ise ölçek durumuna göre t-testi, Anova, Mann Whitney U ve Kruskal Wallis testleri kullanılmıştır. İlk ve ortaöğretimde görev yapan öğretmenlerin öğrenen özerkliğini destekleme davranışlarını serileme düzeylerinin betimlenmesi amacryla frekans, yüzde ve ortalama gibi betimsel tekniklerden yararlanılmıştır. Öğretmenlerin, öğrenen özerkliğini destekleme davranışlarının gerekliliği ile sergilenmesine ilişkin görüşleri arasındaki ilişki düzeyini belirlemek amacıyla Pearson Momentler Çarpımı korelasyon katsayısı kullanılmıştır. Öğretmenlerin, öğrenen özerkliğini destekleme davranışlarının gerekliliği ile sergilenmesine ilişkin görüşleri, bağımsız değişkenlere göre farklılıklarını belirlemede verilerin normal dağıldığı durumlarda t-testi ve varyans analizi, dağılmadığı durumlarda da Mann-Whitney $\mathrm{U}$ ve Kruskall-Vallis testlerinden yararlanılmıştır.

\section{Bulgular}

Araştırmanın birinci alt problemi öğretmenlerin öğrenen özerkliğini destekleme ve ne düzeyde sergilediklerini belirlemeye yöneliktir. Tablo 2 'de öğretmenlerin öğrenen özerkliğini destekleme ve sergileme düzeylerine ilişkin betimsel veriler yer almaktadır. 
Tablo 2. Öğretmenlerin öğrenen özerkliğini destekleme ve sergileme düzeyleri

\begin{tabular}{|c|c|c|c|c|}
\hline \multirow{2}{*}{ Öğrenen Özerkliği } & \multicolumn{2}{|c|}{ Gereklilik } & \multicolumn{2}{|c|}{ Sergileme } \\
\hline & $\mathrm{f}$ & $\%$ & $\mathrm{f}$ & $\%$ \\
\hline Hiçbir zaman & 0 & 0,0 & 0 & 0,0 \\
\hline Çok az & 6 & 0,6 & 21 & 2,0 \\
\hline Ara sira & 71 & 6,6 & 160 & 14,9 \\
\hline Çoğu zaman & 531 & 55,2 & 539 & 50,3 \\
\hline Her zaman & 4 & 37,6 & 351 & 32,8 \\
\hline $\mathrm{N}$ & \multicolumn{2}{|c|}{1071} & \multicolumn{2}{|c|}{1071} \\
\hline Ort. $(\overline{\mathrm{X}})$ & \multicolumn{2}{|c|}{4,09} & \multicolumn{2}{|c|}{3,95} \\
\hline SS & \multicolumn{2}{|c|}{050} & \multicolumn{2}{|c|}{591} \\
\hline
\end{tabular}

Tablo 2'de görüldügüü üzere, araştırmaya katılan öğretmenlerin yarısından fazlasının (\% 55,2) öğrenen özerkliğini destekleme davranışlarını "çoğu zaman" gerekli görmektedirler. Aynı şekilde öğretmenlerin yarısının (\% 50,3) öğrenen özerkliğini “çoğu zaman" destekledikleri görülmektedir.

Araştırmanın ikinci alt problemi, öğretmenlerin öğrenen özerkliğini destekleme davranışlarının gerekliliği ve sergilenmesine ilişkin görüşlerinin cinsiyet, çalıştıkları kurum, deneyim yılı, bölüm ve görev yapılan bölge değişkenlerine göre anlamlı bir farklılık gösterip göstermediğini tespit etmeye yöneliktir. Tablo 3'te öğretmenlerin öğrenen özerkliğini destekleme davranışlarının gerekliliği ve sergilenmesine ilişkin görüşlerinin cinsiyet değişkenine göre farklılıklarını gösteren veriler yer almaktadir.

Tablo 3. Öğretmenlerin öğrenen özerkliğini destekleme davranışlarının gerekliliği ve sergilenmesine ilişkin görüşlerinin cinsiyet değişkenine göre değerlendirilmesi

\begin{tabular}{|c|c|c|c|c|c|c|}
\hline & $\begin{array}{l}\text { Cin- } \\
\text { siyet }\end{array}$ & $\mathrm{N}$ & $\begin{array}{l}\text { Sira Orta- } \\
\text { lamasi }\end{array}$ & $\begin{array}{c}\text { Sira } \\
\text { Toplamı }\end{array}$ & $\begin{array}{c}\text { Mann } \\
\text { Whitney- } \\
\text { U }\end{array}$ & $\mathrm{p}$ \\
\hline $\begin{array}{l}\text { Öğrenen Özerkliği- } \\
\text { ni Destekleme }\end{array}$ & Kadın & 623 & 543,51 & 338607,00 & \multirow{2}{*}{134873,000} & \multirow{2}{*}{,348 } \\
\hline $\begin{array}{l}\text { Davranışlarının } \\
\text { Gerekliliği }\end{array}$ & Erkek & 448 & 525,56 & 235449,00 & & \\
\hline $\begin{array}{l}\text { Öğrenen Özerkliği- } \\
\text { ni Destekleme }\end{array}$ & Kadin & 623 & 543,67 & 338706,00 & \multirow[b]{2}{*}{134774,000} & \multirow[b]{2}{*}{,338 } \\
\hline $\begin{array}{l}\text { Davranışlarını } \\
\text { Sergileme }\end{array}$ & Erkek & 448 & 525,33 & 235350,00 & & \\
\hline
\end{tabular}


Tablo 3 incelendiğinde öğretmenlerin cinsiyetleri öğrenen özerkliğini destekleme davranışlarının gerekliliği ve sergilenmesine ilişkin görüşleri arasında anlamlı bir fark bulunmadığı görülmektedir $(\mathrm{p}>, 05)$.

Tablo 4'de öğretmenlerin öğrenen özerkliğini destekleme davranışlarının gerekliliği ve sergilenmesine ilişkin görüşlerinin öğretmenlerin çalıştıkları kuruma göre farklılıklarını içeren Kruskal-Wallis testi sonuçları yer almaktadır.

Tablo 4. Öğretmenlerin öğrenen özerklĭgini destekleme davranışlarının gerekliliği ve sergilenmesine ilişkin görüşlerinin kurum açısından değerlendirilmesi

\begin{tabular}{|c|c|c|c|c|c|c|}
\hline & Kurum & $\mathrm{N}$ & $\begin{array}{c}\text { Sira Orta- } \\
\text { lamasi }\end{array}$ & Sd & $x^{2}$ & $\mathrm{p}$ \\
\hline & İlkokul & 307 & 604,38 & \multirow{4}{*}{3} & \multirow{4}{*}{22,769} & \multirow{4}{*}{,000 } \\
\hline $\begin{array}{l}\text { Ugrenen } \\
\text { Özorkliŏini }\end{array}$ & Ortaokul & 396 & 516,54 & & & \\
\hline $\begin{array}{l}\text { Uzerkliginı } \\
\text { Destekleme }\end{array}$ & $\begin{array}{l}\text { Lise } \\
\text { Özel }\end{array}$ & 290 & 508,83 & & & \\
\hline $\begin{array}{l}\text { Davranışlarının } \\
\text { Gerekliliği }\end{array}$ & $\begin{array}{l}\text { kurum ve } \\
\text { diğerleri }\end{array}$ & 78 & 466,69 & & & \\
\hline & İlkokul & 307 & 586,40 & \multirow{4}{*}{3} & \multirow{4}{*}{22,537} & \multirow{4}{*}{,000 } \\
\hline $\begin{array}{l}\text { Ugrenen } \\
\text { Özrkliŏini }\end{array}$ & Ortaokul & 396 & 482,31 & & & \\
\hline $\begin{array}{l}\text { Destekleme } \\
\text { Destigini }\end{array}$ & $\begin{array}{l}\text { Lise } \\
\text { Özel }\end{array}$ & 290 & 561,88 & & & \\
\hline $\begin{array}{l}\text { Davranışlarını } \\
\text { Sergileme }\end{array}$ & $\begin{array}{l}\text { kurum ve } \\
\text { diğerleri }\end{array}$ & 78 & 513,98 & & & \\
\hline
\end{tabular}

Tablo 4'e göre, öğretmenlerin öğrenen özerkliğine ilişkin davranışların gerekliliğine inanma düzeylerinin çalıştıkları kurumlara göre anlamlı düzeyde farklılık gösterdiği ortaya çıkmıştır. Grupların sıra ortalamaları incelendiğinde, ilkokulda çalışan öğretmenlerin öğrenen özerkliğinin gerekliliğine diğer kurumlardaki öğretmenlere göre daha fazla inandıkları görülmektedir. Özel kurumlarda çalışan öğretmenlerinin ise öğrenen özerkliğinin gerekliliğine en az inanan öğretmenler olduğu görülmektedir.

Tablodaki verilere göre, öğretmenlerin öğrenen özerkliğini sergileme düzeylerinin anlamlı düzeyde farklılık gösterdiği görülmektedir. Öğrenen özerkliğini sergileme düzeyinin en yüksek olduğu öğretmenlerin ilkokulda görev yapan öğretmenler olduğu görülmektedir. Öğrenen 
özerkliğini sergileme düzeyinin en düşük olduğu öğretmenler ise ortaokul öğretmenleridir.

Tablo 5'te öğretmenlerin öğrenen özerkliğini destekleme davranışlarının gerekliliği ve sergilenmesine ilişkin görüşleri öğretmenlerin deneyim yılı açısından incelenmektedir.

Tablo 5. Öğretmenlerin öğrenen özerkliğini destekleme davranışlarının gerekliliği ve sergilenmesine iliş̧kin görü̧şlerinin deneyim yılı açısından değerlendirilmesi

\begin{tabular}{|c|c|c|c|c|c|c|}
\hline & $\begin{array}{c}\text { Deneyim } \\
\text { Yll }_{1}\end{array}$ & $\mathrm{~N}$ & $\begin{array}{c}\text { Sira Orta- } \\
\text { lamasi }\end{array}$ & $\mathrm{Sd}$ & $x^{2}$ & $\mathrm{p}$ \\
\hline & $1-5 Y_{1}$ & 510 & 509,02 & \multirow{5}{*}{4} & \multirow{5}{*}{22,231} & \multirow{5}{*}{,000 } \\
\hline $\begin{array}{l}\text { Ugrenen } \\
\text { Özorkličrini }\end{array}$ & $6-10 Y_{11}$ & 189 & 513,99 & & & \\
\hline Uzerkilgini & $11-15 Y_{11}$ & 145 & 560,84 & & & \\
\hline $\begin{array}{l}\text { Destekleme } \\
\text { Davranıslarinın }\end{array}$ & $16-20 Y_{1} l$ & 101 & 538,45 & & & \\
\hline Gerekliliği & $\begin{array}{l}21 \text { Yll ve } \\
\text { Ü. }\end{array}$ & 126 & 647,64 & & & \\
\hline Öŏrenen & $1-5 Y_{11}$ & 510 & 497,45 & \multirow{5}{*}{4} & \multirow{5}{*}{45,027} & \multirow{5}{*}{,000 } \\
\hline $\begin{array}{l}\text { Ugrenen } \\
\text { Özorkliŏini }\end{array}$ & $6-10 Y_{1} l$ & 189 & 484,78 & & & \\
\hline $\begin{array}{l}\text { Uzerkliginı } \\
\text { Destekleme }\end{array}$ & $11-15 Y_{1 l}$ & 145 & 596,78 & & & \\
\hline Davranışlarını & $16-20 Y_{1}$ & 101 & 566,40 & & & \\
\hline Sergileme & $\begin{array}{c}21 \text { Yll ve } \\
\text { Ü. }\end{array}$ & 126 & 674,56 & & & \\
\hline
\end{tabular}

Tablo 5'te öğretmenlerin öğrenen özerkliğine ilişkin davranışların gerekliliğine inanma düzeylerinin deneyim yıllarına göre anlamlı düzeyde farklılık gösterdiği görülmektedir. Deneyim yılı 21 yıl ve üzeri olan öğretmenlerin öğrenen özerkliğine ilişkin davranışların gerekliliğine inanma düzeyleri diğer öğretmenlere göre daha yüksektir. Deneyim yılı $1-5$ yıl olan öğretmenlerin ise öğretmenlerin öğrenen özerkliğine ilişkin davranışların gerekliliğine inanma düzeylerinin en düşük olduğu görülmektedir.

Tablodaki veriler incelendiğinde, öğretmenlerin öğrenen özerkliğini sergileme düzeylerinin deneyim yıllarına göre anlamlı bir farklılık gösterdiği görülmektedir. Deneyim yılı 21 yıl ve üzeri olan öğretmenlerin öğrenen özerkliğini sergileme düzeyleri diğer öğretmenlerden yüksektir. Deneyim yılı 6 - 10 yıl olan öğretmenlerin ise öğrenen özerkliğini sergileme düzeylerinin en düşük olduğu ortaya çıkmıştır. 
Tablo 6' da öğretmenlerin öğrenen özerkliğini destekleme davranışlarının gerekliliği ve sergilenmesine ilişkin görüşleri öğretmenlerin bölümleri açısından incelenmektedir.

Tablo 6. Öğretmenlerin öğrenen özerkliğini destekleme davranışlarının gerekliliği ve sergilenmesine ilişkin görüşlerinin bölüm açısından değerlendirilmesi

\begin{tabular}{|c|c|c|c|c|c|c|}
\hline & \multicolumn{6}{|c|}{ Sira } \\
\hline & Bölüm & $\mathrm{N}$ & $\begin{array}{c}\text { Ortala- } \\
\text { masi }\end{array}$ & sd & $x^{2}$ & $\mathrm{p}$ \\
\hline Öğrenen & Sözel & 778 & 548,21 & & & \\
\hline Özerkliğini & Sayısal & 208 & 477,64 & & & \\
\hline Destekleme & Görsel ve Uygu- & 38 & 57266 & 3 & 9,512 & ,023 \\
\hline Davranışları- & lamalı Bilimler & 30 & $3 / 2,00$ & & & \\
\hline nın Gerekliliği & Meslek Der. & 47 & 562,66 & & & \\
\hline Öğgrenen & Sözel & 778 & 542,47 & & & \\
\hline Özerkliğini & Sayısal & 208 & 477,56 & & & \\
\hline Destekleme & Görsel ve Uygu- & 38 & 628,25 & 3 & 14,071 & ,003 \\
\hline Davranışlarını & lamalı Bilimler & & & & & \\
\hline Sergileme & Meslek Der. & 47 & 612,89 & & & \\
\hline
\end{tabular}

Tablo 6'da katılımcı öğretmenlerin bölümlerine göre öğretmenlerin öğrenen özerkliğine ilişkin davranışların gerekliliğine inanma düzeylerinin anlamlı düzeyde farklılık gösterdiği görülmektedir. Görsel ve Uygulamalı Bilimler bölümünde olan öğretmenlerin öğrenen özerkliğine ilişkin davranışların gerekliliğine inanma düzeylerinin en yüksek olduğu, Sayısal bölümünde olan öğretmenlerin ise öğretmenlerin öğrenen özerkliğine ilişkin davranışların gerekliliğine inanma düzeylerinin en düşük olduğu görülmektedir.

Tabloya göre, öğretmenlerin öğrenen özerkliğini sergileme düzeylerinin anlamlı düzeyde farklılaşttı̆ 1 görülmektedir. Öğrenen özerkliğini sergileme düzeyinin en yüksek olduğu öğretmenler Görsel ve Uygulamalı Bilimler bölüm öğretmenleri iken, öğrenen özerkliğini sergileme düzeyinin en düşük olduğu öğretmenler Sayısal bölümünde olan öğretmenler olduğu görülmektedir.

Tablo 7'de öğretmenlerin öğrenen özerkliğini destekleme davranışlarının gerekliliği ve sergilenmesine ilişkin görüşlerinin öğretmenlerin görev yaptıkları bölge açısından değerlendirmeleri yer almaktadır. 
Tablo 7. Öğretmenlerin öğrenen özerkliğini destekleme davranışlarının gerekliliği ve sergilenmesine ilişkin görüşlerinin görev yapılan bölge açısından değerlendirilmesi

\begin{tabular}{|c|c|c|c|c|c|c|}
\hline & \multicolumn{6}{|c|}{ Sira } \\
\hline & Bölge & $\mathrm{N}$ & $\begin{array}{c}\text { Orta- } \\
\text { lamas1 }\end{array}$ & $\mathrm{sd}$ & $x^{2}$ & $\mathrm{p}$ \\
\hline \multirow{7}{*}{$\begin{array}{l}\text { Öğrenen } \\
\text { Özerkliğini } \\
\text { Destekleme } \\
\text { Davranışla- } \\
\text { rının Gerek- } \\
\text { liliği }\end{array}$} & Marmara B. & 45 & 521,03 & \multirow{7}{*}{6} & \multirow{7}{*}{25,762} & \multirow{7}{*}{,000 } \\
\hline & Ege B. & 49 & 416,50 & & & \\
\hline & Akdeniz B. & 45 & 604,03 & & & \\
\hline & Güneydoğu A. B. & 180 & 472,95 & & & \\
\hline & Doğu Anadolu B. & 156 & 541,24 & & & \\
\hline & Karadeniz B. & 35 & 444,27 & & & \\
\hline & İç Anadolu B. & 561 & 566,68 & & & \\
\hline \multirow{7}{*}{$\begin{array}{l}\text { Öğrenen } \\
\text { Özerkliğini } \\
\text { Destekleme } \\
\text { Davranışla- } \\
\text { rını Sergile- } \\
\text { me }\end{array}$} & Marmara B. & 45 & 577,03 & \multirow{7}{*}{6} & \multirow{7}{*}{19,035} & \multirow{7}{*}{,004 } \\
\hline & Ege B. & 49 & 450,21 & & & \\
\hline & Akdeniz B. & 45 & 597,10 & & & \\
\hline & Güneydoğu A. B. & 180 & 478,47 & & & \\
\hline & Doğu Anadolu B. & 156 & 517,29 & & & \\
\hline & Karadeniz B. & 35 & 470,01 & & & \\
\hline & İç Anadolu B. & 561 & 563,08 & & & \\
\hline
\end{tabular}

Tablo 7'de görüldüğü üzere katılımcı öğretmenlerin görev yaptıkları bölgeye göre öğretmenlerin öğrenen özerkliğine ilişkin davranışların gerekliliğine inanma düzeylerinin anlamlı düzeyde farklılık gösterdiği görülmektedir. Akdeniz Bölgesinde görev yapan öğretmenlerin öğrenen özerkliğine ilişkin davranışların gerekliliğine inanma düzeyleri en yüksek iken, Ege Bölgesinde görev yapan öğretmenlerin öğrenen özerkliğine ilişkin davranışların gerekliliğine inanma düzeyleri en düşüktür.

Tabloya göre katılımcı öğretmenlerin öğrenen özerkliğini sergileme düzeylerinin görev yaptıkları bölgeye göre anlamlı düzeyde farklılık gösterdiği görülmektedir. Öğrenen özerkliğini sergileme düzeyi en yüksek olan öğretmenler Akdeniz Bölgesinde görev yapan öğretmenler iken, öğrenen özerkliğini sergileme düzeyi en düşük olan öğretmenler Ege Bölgesinde görev yapan öğretmenlerdir.

Araştırmanın üçüncü alt problemi öğretmenlerin öğrenen özerkliğini destekleme davranışlarının gerekliliği ile sergilenmesine ilişkin görüşleri arasındaki ilişkiyi belirlemektir. Tablo 8'de öğretmenlerin öğrenen özerkliğini destekleme davranışlarının gerekliliği ile sergilenmesine ilişkin görüşleri arasındaki ilişki incelenmektedir. 
Öğretmenlerin Öğrenen Özerkliğini Destekleme ve Sergileme Düzeyleri Arasındaki İlişkinin İncelenmesi

Tablo 8. Öğretmenlerin öğrenen özerkliğini destekleme davranışlarının gerekliliği ile sergilenmesine ilişkin görüşleri arasındaki ilişkinin incelenmesi

\begin{tabular}{lccccc}
\hline & $\mathrm{N}$ & $\overline{\mathrm{X}}$ & $\mathrm{ss}$ & $\mathrm{p}$ & $\mathrm{r}$ \\
\hline Öğrenen Özerkliğini Destekleme & 1071 & 4,09 &, 50 & \multirow{2}{*}{000} & \multirow{2}{*}{, 676} \\
Öğrenen Özerkliğini Segileme & 1071 & 3,95 &, 59 & & \\
\hline
\end{tabular}

Tablo 8 incelendiğinde katılımcı öğretmenlerin öğrenen özerkliğini destekleme davranışlarının gerekliliği ile sergilenmesine ilişkin görüşleri arasında pozitif yönde $(\mathrm{r}=, 676)$ anlamlı bir ilişki olduğu görülmektedir. Bulunan değer ,05 düzeyinde istatistiksel olarak anlamlı bulunmuştur. Buna göre öğretmenlerin öğrenen özerkliğinin gerekliliğine inandıkları oranda bu davranışları gösterdiklerini göstermektedir.

\section{Sonuç, Tartışma ve Öneriler}

Öğretmenlerin öğrenen özerkliklerini destekleme ve sergileme davranışları arasındaki ilişkiyi incelemeye yönelik yapılan bu çalışmada ulaşılan sonuçlar ve alanda yapılan çalışmalar ile karşılaştırmalar, araştırmanın alt problemleri çerçevesinde aşağıda verilmektedir.

Yapılan bu çalışmada, araştırmaya katılan öğretmenlerin yarısından fazlasının $(\% 55,2)$ öğrenen özerkliğini destekleme davranışlarını "çoğu zaman" gerekli gördüğü sonucuna ulaşılmıştır. Öğretmenlerin yarısının ise $(\% 50,3)$ öğrenen özerkliğini destekleme davranışlarını "çoğu zaman" sergiledikleri sonucuna ulaşılmıştır. Bu çalışmanın sonuçlarına benzer olarak, Oğuz (2013) tarafından yapılan bir çalışmada araştırmaya katılan öğretmenlerin öğrenen özerkliğini destekleme davranışlarının "her zaman" gerekli olduğunu ve bu davranışları "çoğu zaman" sergilediklerini belirtmişlerdir. Öğretmenlerin öğrenen özerkliğini destekleme davranışlarının gerekli gördükleri düzeyde bu davranışları sergiledikleri görülmektedir. Ancak öğrenen özerkliğinin her zaman çok önemli olduğunun bilinmesi ve öğretmenler tarafından bu davranışların her zaman sergilenmesi gerekmektedir.

$\mathrm{Bu}$ çalışmada öğretmenlerin cinsiyetlerine göre öğrenen özerkliğini destekleme davranışlarının gerekliliği ve sergilenmesine ilişkin görüşleri arasında anlamlı bir fark bulunmasa kadın öğretmenlerin erkek öğret- 
menlere oranla öğrenen özerkliğini destekleme davranışlarının gerekliliğine ve sergilenmesine ilişkin sonuçları daha yüksektir. Bu çalışmadan farklı olarak Oğuz (2013) tarafından yapılan bir çalışmada öğretmenlerin cinsiyetlerine göre öğrenen özerkliğini destekleme davranışları ve bu davranışları sergileme düzeyleri arasında anlamlı bir fark bulunmuştur. Kadın öğretmenlerin öğrenen özerkliğini destekleme davranışlarının gerekliliğine ilişkin görüşleri ve bu davranışları sergileme düzeyleri erkek öğretmenlerden daha yüksektir. Eren (2015) tarafından yapılan İngilizce öğretmenlerinin öğrenen özerkliğini geliştirmeye yönelik görüşlerinin incelendiği bir çalışmada da kadın öğretmenlerin erkek öğretmenlerden daha destekleyici olduğu sonucuna ulaşılmıştır.

Öğretmenlerin çalıştıkları kuruma göre öğrenen özerkliğini destekleme davranışlarının gerekliliği ve sergilenmesine ilişkin görüşleri arasında anlamlı düzeyde fark olduğu sonucuna ulaşılmıştır. Öğrenen özerkliğini destekleme davranışlarının gerekliliğine ilişkin inançları ilkokul öğretmenlerinde en yüksek iken, özel kurumlarda çalışan öğretmenlerin inançları en düşük düzeydedir. Öğrenen özerkliğini destekleme davranışlarının sergilenmesi ise yine ilkokul öğretmenlerinde en yüksek düzeyde iken ortaokul öğretmenlerinin bu davranışları sergileme düzeyi en düşüktür. Bu durum ilkokul öğretmenlerinin öğrencilere sorumluluk bilincinin aşılanmasında daha dikkatli davrandıklarının göstergesi olabilir. Aynı dikkatin diğer kurumlarda çalışan öğretmenlerde de olabilmesi için öğrenen özerkliğinin öneminin kavranması ve öğretim sürecinde çok önemli bir yer aldığının unutulmaması gerekmektedir. Bunun yanısıra ilkokul ögretmenlerinin bir sınıftan sorumlu olması ve o sınıftaki öğrenciler ile öğrenme sürecinde daha fazla yer alması bu durumun sebepleri arasında yer alabilir. Ayrıca ilkokul kademesinden sonra sınav odaklı bir öğrenme sürecine girilmesi öğretmenlerin daha çok bu yönde çalışmalar yapmasının bu davranışları daha az sergilemelerine neden olduğu düşünülebilir.

Çalışmada, öğretmenlerin öğrenen özerkliğini destekleme davranışlarının gerekliliğine ilişkin görüşleri deneyim yıllarına göre anlamlı düzeyde farklılık gösterdiği sonucuna ulaşılmıştır. 21 yıl ve üzeri deneyim yılına sahip olan öğretmenlerin öğrenen özerkliğini destekleme davranışlarının gerekliliğine ilişkin görüşleri en yüksek düzeydedir. Deneyim yılı 1 - 5 yıl olan öğretmenlerin ise öğrenen özerkliğini destekleme dav- 
ranışlarının gerekliliğine ilişkin düzeyleri en düşüktür. Öğretmenlerin öğrenen özerkliğini destekleme davranışlarını sergileme düzeyleri de deneyim yıllarına göre anlamlı bir fark göstermektedir. Deneyim yılı 21 yıl ve üzeri olan öğretmenlerin öğrenen özerkliğini destekleme davranışlarını sergileme düzeyleri en yüksek iken, 6 - 10 yıl deneyim yılına sahip olan öğretmenlerin öğrenen özerkliğini destekleme davranışlarını sergileme düzeyleri en düşüktür. Güvenç (2011) tarafından yapılan bir çalışmada ise sınıf öğretmenlerinin kıdemleri arttıkça özerklik desteklerinin azaldığı bulgusuna ulaşılmıştır. Ancak bu fark istatistiksel olarak anlamlı bulunmamıştır. Deneyim yılı daha az olan öğretmenlerin öğrenen özerkliğini destekleme düzeylerinin az olması daha az tecrübeli olmalarından kaynaklandığı söylenebilir.

Öğretmenlerin bölümlerine göre öğrenen özerkliğini destekleme davranışlarının gerekliliğine ilişkin görüşleri arasında anlamlı bir fark olduğu ortaya çıkmıştır. Görsel ve Uygulamalı Bilimler bölümünde olan öğretmenlerin öğrenen özerkliğini destekleme davranışlarının gerekliliğine ilişkin görüşleri en yüksek düzeydedir. Sayısal bölümünde olan öğretmenlerin ise öğrenen özerkliğini destekleme davranışlarının gerekliliğine ilişkin görüşleri en düşük düzeydedir. Öğretmenlerin öğrenen özerkliğini destekleme davranışlarını sergileme düzeyleri de bölümlerine göre anlamlı bir fark göstermektedir. Öğrenen özerkliğini destekleme davranışlarını sergileme düzeyleri en yüksek olan öğretmenler Görsel ve Uygulamalı Bilimler bölümü öğretmenleridir. Öğrenen özerkliğini destekleme davranışlarını sergileme düzeyleri en düşük olan öğretmenler ise Sayısal bölümünde olan öğretmenlerdir. Güvenç ve Güvenç (2011) Fen ve Teknoloji öğretmenlerinin özerklik desteklerini incelemek amacıyla yaptıkları çalışmasında öğretmenlerin özerklik desteklerinin düşük olduğu sonucuna ulaşmıştır. Yılmaz, Oğuz ve Altınkurt (2014) tarafından yapılan bir çalışmada ise öğrenen özerkliğini destekleme davranışlarını sergileme düzeyleri ise sınıf ve branş öğretmenleri arasında anlamlı düzeyde farklılık göstermektedir. Sınıf öğretmenleri branş öğretmenlerine göre öğrenen özerkliğini destekleme davranışlarını daha fazla sergilemektedir. Sonuçların farklı çıkması öğretmenlerin branşlarına göre ders saatinin az veya çok olmasından kaynaklanabilir. Sınıf öğretmenlerinin öğrenciler ile daha fazla ders saatine sahip olması onları daha iyi tanımalarına ve kişisel özelliklerine göre öğrencilerin özerkliğini destekleyici 
davranışları daha fazla sergilemelerine olanak sağlamaktadır. Ancak ülkemizde branş derslerine sınav sisteminin getirdiği olumsuz etki sebebiyle fazla önem verilmemektedir. Bu derslere daha fazla önem verilmesi branş öğretmenlerinin de özerklik destekleyici davranışları sergilemelerine katkı sağlayacaktır. Tüm branş öğretmenlerinin öğrenen özerkliğini destekleyici davranışlar sergilemesinin önemini öğrenmeleri ve bu farklılığın sebebinin ne olduğu üzerinde çalışlacak daha fazla araştırma yapılması önerilmektedir.

Çalışmada öğretmenlerin görev yaptıkları bölgeye göre öğrenen özerkliğini destekleme davranışlarına ilişkin görüşleri ve görev yaptıkları bölgeye göre öğrenen özerkliğini destekleme davranışlarını sergileme düzeyleri arasında anlamlı düzeyde bir fark olduğu görülmüştür. Öğrenen özerkliğini destekleme davranışların ilişkin görüşleri ve bu davranışları sergileme düzeyleri en yüksek olan öğretmenler Akdeniz Bölgesinde görev yapan öğretmenler iken, Ege Bölgesinde görev yapan öğretmenlerin öğrenen özerkliğini destekleme davranışlarına ilişkin görüşleri ve bu davranışları sergileme düzeyleri en düşük düzeydedir. Öğretmenlerin öğrenen özerkliğini destekleme düzeylerinin ne düzeyde olduğuna dair farklı bölgelerden çalışma grupları ile daha fazla çalışma yapılmalıdır.

Bu çalışmada öğretmenlerin öğrenen özerkliğini destekleme davranışlarının gerekliliği ile bu davranışların sergilenmesine ilişkin görüşleri arasında pozitif yönlü $(\mathrm{r}=, 676)$ anlamlı bir ilişki olduğu sonucuna ulaşılmıştır. Öğretmenlerin öğrenen özerkliğini destekleme davranışlarının gerekliliğine inandıkları ölçüde bu davranışları sergiledikleri sonucu çıkmaktadır.

Öğretmenlerin öğrenen özerkliğini destekleme davranışlarını sergileme düzeyleri bu davranışları ne kadar gerekli gördükleri ile ilişkilidir. Bu davranışların sergilenme düzeylerinin artırılabilmesi için öğretmenlerin kişisel olarak kendilerini geliştirmeleri, üniversitelerde öğrenen özerkliğinin önemini vurgulayacak dersler olmalı ve bu alanda öğretmenleri ve öğretmen eğitimcilerini daha fazla bilgilendirmek amacıyla daha çok araştırma yapılması gerekmektedir. 


\section{Kaynakça}

Aydoğdu, C. (2009). Yabancı dil öğretiminde otonom öğrenme: neden ve nasil?. Journal of International Social Research, 2(8), 68-74.

Bay, E., Gündoğdu, K., ve Kaya, H. I. (2010). The perceptions of prospective teachers on the democratic aspects of the constructivist learning environment. Electronic Journal of Research in Educational Psychology, 8(2), 617-642.

Camilleri, G. (1997). Learner autonomy: The teachers' views (European Center of Modern Languages).

Deci, E. L., ve Ryan, R. M. (1987). The support of autonomy and the control of behavior. Journal of Personality and Social Psychology, 53(6), 1024-1037.

Duffy, T. M. ve Jonassen, D. H. (1992). Constructivist and the technology of instruction: A conversation. Hillsdale, NJ: Lawrence Erlbaum Associates.

Eker, D. N. (2010). Türkçe'nin yabancı dil olarak öğretiminde öğrenen özerkli$\breve{g}$ i. Yayınlanmamış Yüksek Lisans Tezi. Ankara Üniversitesi Sosyal Bilimler Enstitüsü, Ankara.

Eren, İ. (2015). Ortaokul İngilizce öğretmenlerinin öğrencilerde öğrenen özerkliği geliştirmeye yönelik görüşlerinin incelenmesi. Yayınlanmamış Yüksek Lisans Tezi. Kahramanmaraş Sütçü İmam Üniversitesi Sosyal Bilimler Enstitüsü, Kahramanmaraş.

Ergür, D. O. (2010). Öğrenen özerkliğinin kazandırılmasında öğretmenin rolü. In International Conference on New Trends in Education and Their Implications, 354-359.

Gray, A. J. (1997). Constructivist teaching and learning. Saskatchewan School Trustees Association.

Güvenç, H. (2011). Sınıf öğretmenlerinin özerklik destekleri ve mesleki özyeterlik algıları. Kuram ve Uygulamada Ĕ̆itim Yönetimi [Educational Administration: Theory and Practice], 17(1), 99-116.

Güvenç, E. ve Güvenç, H. (2011). “Fen ve teknoloji öğretmenlerinin özerklik destekleri ve sınıf yönetim biçemleri." 20. Ulusal Eğitim Bilimleri Kurultayı'nda sunulan bildiri, Mehmet Akif Ersoy Üniversitesi, Eğitim Fakültesi, Burdur. 
Holec, H. (1991). Autonomie De L'apprenant: De L'enseignement A L'apprentissage. Education Permanente, 107, 1-5.

http://www. warwick. ac. uk/ elsdr/Teacher_autonomy. pdf. (05.05.17 tarihinde erişilmiştir.)

Oğuz, A. (2013). Teacher's views about supporting learner autonomy. Journal of Human Sciences, 10(1), 1273-1297.

Oğuz, A., Altınkurt, Y., Yılmaz, K., ve Hatipoğlu, S. (2014). Öğretmenlerin eğitim inançları ile öğrenen özerkliğini destekleme davranışları arasındaki ilişki. Turkish Journal of Educational Studies, 1(1), 3778.

Özçelik, N. (2015). Üniversitede Fransızcanın ikinci yabancı dil olarak öğretimi/öğreniminde öğrenen özerkliği. Hacettepe Üniversitesi Eğitim Fakültesi Dergisi, 30(3), 102-115.

Reeve, J. ve Jang, H. (2006). What teachers say and do to support students' autonomy during a learning activity. Journal of Educational Psychology, 98(1), 209-218.

Reeve, J., Jang, H., Carrell, D., Jeon, S., ve Barch, J. (2004). Enhancing students' engagement by increasing teachers' autonomy support. Motivation and emotion, 28(2), 147-169.

Smith, R. C. (2003). Teacher education for teacher-learner autonomy. In Symposium for Language Teacher Educators: Papers from Three IALS Symposia (CD-ROM). Edinburgh: IALS, University of Edinburgh.

Smith, R. C. (2000). Starting with ourselves: Teacher-learner autonomy in language learning. In B. Sinclair, I. McGrath and T. Lamb (eds.) Learner autonomy, teacher autonomy: Future directions. London: Longman. 89-99.

Uşun, S., Yakar, A., ve Kahya, O. (2016). Sınıf öğretmenlerinin ve ortaokul branş öğretmenlerinin öğrenen özerkliğini destekleme davranışlarının incelenmesi. Cumhuriyet International Journal of Education, 5, 72-81.

Wang, P. (2011). Constructivism and learner autonomy in foreign language teaching and learning: To what extent does theory inform practice. Theory and Practice in Language Studies, 1(3), 273-277.

Wenden, A. (1991). Learner Strategies for Learner Autonomy. Great Britain: Prentice Hall. 
Öğretmenlerin Öğrenen Özerkliğini Destekleme ve Sergileme Düzeyleri Arasındaki İlişkinin İncelenmesi

Yılmaz, K., Oğuz, A., ve Altınkurt, Y. (2014). Öğretmenlerin liderlik davranışları ile öğrenen özerkliğini destekleme davranışları arasındaki ilişki. Hacettepe Üniversitesi Ĕ̆itim Fakültesi Dergisi, 32(3), 659-675.

\section{Kaynakça Bilgisi / Citation Information}

Durmuşçelebi, M. ve Çetinkaya, M. (2018). Öğretmenlerin öğrenen özerkliğini destekleme ve sergileme düzeyleri arasındaki ilişkinin incelenmesi. OPUS - Uluslararası Toplum Araştırmaları Dergisi, 8(Gençlik Araştırmaları Özel Sayısı), 330-348. 